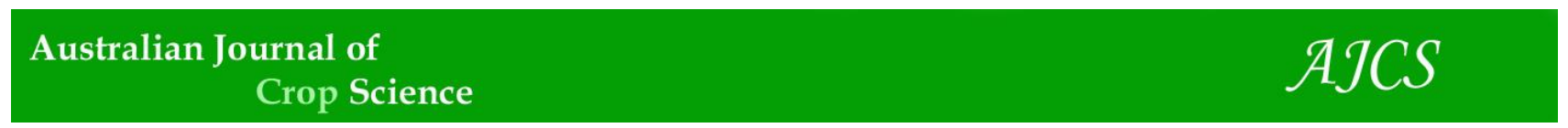

AJCS 14(08):1427-1432 (2020)

ISSN:1835-2707

doi: 10.21475/ajcs.20.14.09.p2440

\title{
Morphophysiology of ornamental sunflower plant irrigated with saline water and application of silicon
}

\author{
Lunara de Sousa Alves ${ }^{1}$, Mário Leno Martins Véras ${ }^{* 2}$, Nelto Almeida de Sousa ${ }^{3}$, Fernanda Ferreira de \\ Araújo ${ }^{4}$, Edinete Nunes de Melo ${ }^{1}$, Ewerton Gonçalves de Abrantes ${ }^{5}$, Adriana Pricilla Jales Dantas ${ }^{1}$, Thiago \\ Jardelino Dias ${ }^{1}$, Ana Carolina Bezerra ${ }^{1}$, Márcia Paloma da Silva Leal ${ }^{1}$ \\ ${ }^{1}$ Federal University of Paraíba, Department of Phytotechnics and Environmental Sciences, Highway BR 079 - km 12, \\ 58397-000, Areia, PB, Brazil \\ ${ }^{2}$ Federal Institute of Amapá, Highway BR 210 - km 103, 68997-000, Porto Grande, AP, Brazil \\ ${ }^{3}$ Federal University of Santa Maria, Building 77, Room 05, Roraima no 1000, Camobi Neighborhood, 97105-900, \\ Santa Maria, RS, Brazil \\ ${ }^{4}$ Federal University of Viçosa, Department of Phytotechnics, Avenue Peter Henry Rolfs, University Campus, 36570- \\ 900, Viçosa, MG, Brazil \\ ${ }^{5}$ Federal University of Paraíba, Soil and Rural Engineering Department, Highway BR 079 - km 12, 58397-000, Areia, \\ PB, Brazil
}

*Corresponding author: mario.veras1992@gmail.com

Abstract

The use of saline water in agriculture is an alternative, especially in regions with water scarcity, such as the Brazilian Northeast semiarid. However, salt stress considerably reduces plant growth and development. In this sense, the objective was to evaluate the morphophysiological responses of the ornamental sunflower irrigated with saline water under application of silicon. The experimental design was entirely randomized conducted in a factorial $4 \times 5$ with 6 replicates, related to four electrical conductivity of the irrigation water $(E C W): 0.5 ; 1.5 ; 2.5$ and $3.5 \mathrm{dS} \mathrm{m}^{-1}$ five silicon rates: $0,50,100,150$ and $200 \mathrm{mg} \mathrm{L}^{-1}$, proceeding to the evaluation of: plant height, stem diameter, number of leaves, absolute and relative growth rates, initial fluorescence, maximum fluorescence, variable fluorescence, maximum efficiency of the photochemical process in FSII, potential quantum yield of photosystem II, stomatal conductance and instant efficiency in the use of water. The gradual increase of ECw reduces growth, chlorophyll fluorescence $a$ and stomatal opening of the ornamental sunflower plants. The application of silicon above $100 \mathrm{mg} \mathrm{L}^{-1}$ promotes a decrease in ornamental sunflower stomatal conductance. It is recommended to irrigate ornamental sunflower plants with water of $0.5 \mathrm{dS} \mathrm{m}^{-1}$ associated with the application of $100 \mathrm{mg} \mathrm{L}^{-1}$ of silicon.

Keywords: Helianthus annuus L.; saline water; plant physiology; potassium silicate.

Introduction

Sunflower (Helianthus annuus L.) is worldwide cultivated, due to its good adaptability to various conditions, either for an ornamental vase or cut flower production. In addition, the sunflower is one of the ornamental plants most required in the market, because it is very appreciated for its exuberance in the form and color of the inflorescence. The ornamental sunflower cycle lasts about 50 days, considered, in agronomic terms, great for cultivation in a greenhouse (Wanderley et al., 2014; Mushke et al., 2019; Sarwar \& Shabbaz, 2019).

Flower production presents enormous social and economic importance in Brazil (Silva et al., 2015), and ornamental sunflower production seems to be a profitable alternative, especially for limited production areas. However, as in the cultivation of other ornamental plants, the use of quality water for irrigation is extremely important to obtain the expected productivity, it makes water management a huge challenge for farmers, especially in the Brazilian northeastern semi-arid region due to water resources scarcity (Oliveira et al., 2017).

Due to the water scarcity, the search for alternative sources is essential for irrigation, and thus, there is a necessity of search for new strategies to enable the use of brackish water effectively in sunflower production process, without compromising production (Santos Junior et al., 2013). However, irrigation with saline water can reduce plants photosynthetic capacity and negatively affect the plants growth and development (Silva et al., 2013). Studies indicate that the sunflower irrigated with saline water have their growth and development adversely compromised (Santos Junior et al., 2013; Sousa Júnior et al., 2017).

As alternatives to reduce the deleterious effects of salt stress, may be to use attenuating substances as silicon (Si) (Alzahrani et al., 2018; Gomes et al., 2018), it has been used 
despite not being considered an essential element for plants, silicon presents beneficial effects on plant development (Guntzer et al., 2012). In recent years, research indicates that the silicon may mitigate the effects of abiotic stresses, such as salinity and drought (Zhu \& Gong, 2014; Sahebi et al., 2016). Furthermore, the application of silicon may promote further growth of many plants species (sunflower, cotton and castor) subjected to handling irrigation with saline water (Silva et al., 2009; Ferraz et al., 2014).

Due to the lack of studies involving the use of attenuators of salt stress, especially in ornamental plants such as sunflower, studies to evaluate the silicon potential are essential as an alternative to reduce the harmful effects of saline water in sunflower cultivation. In this regard, the aim was to evaluate morphophysiological responses of ornamental sunflower irrigated with saline water in function of foliar silicon application.

\section{Results and Discussion}

\section{Plant height}

It was observed interaction of irrigation water salinity (ECW) $\times$ silicon (Si) just for plant height at 25, 35 and 45 DAS, stem diameter at 15,35 and 45 DAS, initial fluorescence and quantum efficiency of photosystem II. There was a significant effect of ECw for stem diameter at 25 and 35 DAS, number of leaves at 15 and 45 DAS and stomatal conductance. The Si rates significantly influenced only the stem diameter at 24 and 35 DAS and stomatal conductance. The response surface presented in Figure 1 indicates that the height of ornamental sunflower plants had increased over the evaluation period, obtaining the maximum values of $41.98 ; 60.17$ and and $79,23 \mathrm{~cm}$ at $25 ; 35$ and 45 DAS, it was found that highest plant height $(85.63 \mathrm{~cm})$ was observed in plants irrigated with lower salinity water $(0.5 \mathrm{dS}$ $\mathrm{m}^{-1}$ ) and the smallest height $(40.21 \mathrm{~cm})$ with irrigation higher salinity water $\left(3.5 \mathrm{dS} \mathrm{m}^{-1}\right)$, decreased to $112.95 \%$ compared between plants irrigated with higher and lower salinity water. A work with sunflower cV. "EMBRAPA 122-V2000" presented by Santos et al. (2017) was found that plant height decreased $8.74,12.49,12.74,10.75$ and $10.04 \%$ at 15 , $30,45,60$ and 75 DAS, respectively in plants irrigated with water of $0.7,1.7,2.7,3.7$ and $4.7 \mathrm{dS} \mathrm{m}^{-1}$, smaller percentage compared with obtained in this work, which can be explained by the studied variety being ornamental, and could be more sensitive to deleterious effects of salt stress. Ribeiro et al. (2015) also found that increasing irrigation water salinity reduces the plant height of sunflower plants, when observed that after 75 DAS irrigated plants with lower salinity $\left(0.6 \mathrm{dS} \mathrm{m}^{-1}\right)$ reached $158 \mathrm{~cm}$, while the higher water salinity level $\left(4.5 \mathrm{dS} \mathrm{m}^{-1}\right)$ increased to $113 \mathrm{~cm}$, values these higher than observed in Figure 1, although this may be explained because cultivar "Sol noturno" is ornamental.

The plant height decrease of ornamental sunflower plants may have been caused by the harmful effects of salts to the plants, since plant growth becomes slower, it results in an unbalanced plant nutrition, such as reducing the absorption of nutrients (Yadav et al., 2011; Shahzad et al., 2012).

\section{Stem diameter}

$\mathrm{ECW}$ reduced the stem diameter of the ornamental sunflower plants at 25 and 35 DAS, though at 25 DAS, the increase of ECW sharply restricted stem diameter growth, by observing a decrease of $21.49 \%$ in plants irrigated with water $0.5 \mathrm{dS} \mathrm{m}^{-1}$ comparing with those irrigated with water of $3.5 \mathrm{dS} \mathrm{m} \mathrm{m}^{-1}$. At $35 \mathrm{DAS}$, there is a relative adjustment of the plants for stem expansion, because the increase salinity irrigation water decreased the stem diameter, obtaining up $8.50 \mathrm{~mm}$ in plants conducted with water of $0.5 \mathrm{dS} \mathrm{m}^{-1}$ and the lower decrease observed at 25 DAS, with $8.23 \%$ in plants irrigated with water of $0.5 \mathrm{dS} \mathrm{m}^{-1}$ compared to those irrigated with water of $3.5 \mathrm{dS} \mathrm{m}^{-1}$ (Figure 2A).

Santos Junior et al. (2013) also found in ornamental sunflower similar behavior to that observed in cv. "Anão-deJardim" that presented a decrease of $55.7 \%$ per unit increment of ECW when compared stem diameter of plants under $9 \mathrm{dS} \mathrm{m}^{-1}$ compared to plants under $1.7 \mathrm{dS} \mathrm{m}^{-1} \mathrm{ECW}$.

The results obtained in this study corroborate to those found by Silva et al. (2009) when observed that the increase of the $\mathrm{ECW}$ have compromised stem diameter of sunflower, wherein the plants irrigated with water of $3.5 \mathrm{dS} \mathrm{m}^{-1}$ had a diameter of $4.7 \mathrm{~mm}$ at $42 \mathrm{DAS}$, lower than those presented in Figure 2 . Ribeiro et al. (2015) also found that higher water salinity level reduced the stem diameter of sunflower plants cV. "EMBRAPA 122-V2000", observing the plants under water of $0.6 \mathrm{dS} \mathrm{m}^{-1}$ and $4.5 \mathrm{dS} \mathrm{m}^{-1}$ they had final diameters of $15.8 \mathrm{~mm}$ and $10.3 \mathrm{~mm}$, respectively, being smaller than those observed in this study.

The stem diameter of ornamental sunflower plants grew with the increase of evaluation periods, with the biggest stem diameter at 45 DAS with $8.29 \mathrm{~mm}$ and the smallest stem diameter of 3.93 at 15 DAS. With the increase of $\mathrm{Si}$ rates, could observe an increase in stem diameter of sunflower, with maximum values in $200 \mathrm{mg} \mathrm{L}^{-1} \mathrm{Si}$ rate was obtained 4.13; 8.55 e $8.70 \mathrm{~mm}$ at 15, 35 and 45 DAS, in this sequence (Figure $2 \mathrm{~B}$ ). This increase is possibly due to the increase in the activity of the antioxidant metabolism enzymes, mainly protecting against the action of free radicals and consequent cellular damages, providing greater expansion and cell division directly reflecting in the growth of ornamental sunflower plant (Maia et al., 2015).

Probably, smaller stems diameters of ornamental sunflower plants irrigated with saline water is especially due to their reduction in water absorption, since the excessive accumulation of salts causes a reduction in the osmotic potential of the soil solution, and may cause ionic toxicity, nutritional imbalance or both (Islam et al., 2017); Thus, with salts excess that could be harmful to the sunflower plants, the water absorption may have reduced, thus leading to water deficiency, and consequently decrease in growth.

\section{Number of leaves}

The number of leaves of ornamental sunflower plants reduced 11.77 and $10.25 \%$ in this order at 15 and 45 DAS, as preceded the increase of ECW obtaining maximum values of 6.66 and 22.13 leaves in the plant with water of $0.5 \mathrm{dS} \mathrm{m}^{-1}$. Furthermore, there was evidence that increasing the irrigation water salinity to $3.5 \mathrm{dS} \mathrm{m}^{-1}$ was observed reduction in the number of leaves to 5.66 and 19.86 (Figure 3).

The reduction in the number of leaves can be attributed to salts excess, which compromise the physiological activities, leading to osmotic stress, and thus an imbalance in water relations, changes in the absorption and utilization of essential nutrients, also an accumulation of toxic ions (Calvet et al., 2013). In addition, the stress caused by salts may have reduced leaf expansion of ornamental sunflower plants, 
Table 1. Soil physical and chemical properties and water characterization.

\begin{tabular}{|c|c|c|c|c|c|}
\hline $\begin{array}{ll}\text { Soil } & \text { physical } \\
\text { attributes } & \\
\end{array}$ & Values & Soil Fertility & Values & Water attributes & Values \\
\hline $\mathrm{Cs}\left(\mathrm{g} \mathrm{kg}^{-1}\right)$ & 454 & $\mathrm{pH}$ in water $(1: 2.5)$ & 7.03 & $\mathrm{pH}$ & 7.90 \\
\hline Fs $\left(\mathrm{g} \mathrm{kg}^{-1}\right)$ & 435 & $P\left(m g d m^{-3}\right)$ & 28.88 & $\mathrm{EC}\left(\mathrm{dS} \mathrm{m^{-1 }}\right)$ & 0.68 \\
\hline Silt $\left(\mathrm{g} \mathrm{kg}^{-1}\right)$ & 192 & $\mathrm{~K}^{+}\left(\mathrm{mg} \mathrm{dm}{ }^{-3}\right)$ & 290.00 & $\mathrm{Ca}^{+2}\left(\mathrm{mmol}_{\mathrm{c}} \mathrm{L}^{-1}\right)$ & 1.56 \\
\hline Clay $\left(\mathrm{g} \mathrm{kg}^{-1}\right)$ & 219 & $\mathrm{Na}^{+}\left(\mathrm{cmol}_{\mathrm{c}} \mathrm{dm}^{-3}\right)$ & 0.31 & $\mathrm{Mg}^{+2}\left(\mathrm{mmol}_{\mathrm{c}} \mathrm{L}^{-1}\right)$ & 0.32 \\
\hline $\operatorname{Dcw}\left(\mathrm{g} \mathrm{kg}^{-1}\right)$ & 27 & $\mathrm{Ca}^{+2}\left(\mathrm{cmol}_{\mathrm{c}} \mathrm{dm}^{-3}\right)$ & 4.50 & $\mathrm{Na}^{+}\left(\mathrm{mmol}_{\mathrm{c}} \mathrm{L}^{-1}\right)$ & 3.81 \\
\hline $\mathrm{Df}(\%)$ & 87.70 & $\mathrm{Mg}^{+2}\left(\mathrm{cmol}_{\mathrm{c}} \mathrm{dm}^{-3}\right)$ & 2.10 & $\mathrm{~K}^{+}\left(\mathrm{mmol}_{\mathrm{c}} \mathrm{L}^{-1}\right)$ & 0.28 \\
\hline Ds $\left(\mathrm{g} \mathrm{cm}^{-3}\right)$ & 1.00 & $\mathrm{Al}^{+3}\left(\mathrm{cmol}_{\mathrm{c}} \mathrm{dm}^{-3}\right)$ & 0.00 & $\mathrm{SO}_{4}^{-2}\left(\mathrm{mmol}_{\mathrm{c}} \mathrm{L}^{-1}\right)$ & 0.50 \\
\hline $\operatorname{Pd}\left(\mathrm{g} \mathrm{cm}^{-3}\right)$ & 2.61 & $\mathrm{H}^{+}+\mathrm{Al}^{+3}\left(\mathrm{cmol}_{\mathrm{c}} \mathrm{dm}^{-3}\right)$ & 1.73 & $\mathrm{CO}_{3}^{-2}\left(\mathrm{mmol}_{\mathrm{c}} \mathrm{L}^{-1}\right)$ & 0.40 \\
\hline $\operatorname{Tp}\left(\mathrm{m}^{3} \mathrm{~m}^{-3}\right)$ & 0.62 & $\mathrm{Sb}\left(\mathrm{cmol}_{\mathrm{c}} \mathrm{dm}^{-3}\right)$ & 7.65 & $\mathrm{HCO}_{3}^{-}\left(\mathrm{mmol}_{\mathrm{c}} \mathrm{L}^{-1}\right)$ & 7.50 \\
\hline Ucc $\left(\mathrm{g} \mathrm{kg}^{-1}\right)$ & 169.30 & $\operatorname{CEC}\left(\mathrm{cmol}_{\mathrm{c}} \mathrm{dm}^{-3}\right)$ & 9.38 & $\mathrm{Cl}^{-}\left(\mathrm{mmol}_{\mathrm{c}} \mathrm{L}^{-1}\right)$ & 1.00 \\
\hline Upmp $\left(\mathrm{g} \mathrm{kg}^{-1}\right)$ & 117.91 & $\mathrm{~V}(\%)$ & 81.56 & $\operatorname{SAR}\left(\mathrm{mmol}_{\mathrm{c}} \mathrm{L}^{-1}\right)^{-0.5}$ & 3.93 \\
\hline Wa $\left(\mathrm{g} \mathrm{kg}^{-1}\right)$ & 51.40 & $\mathrm{~m}(\%)$ & 0.00 & Classification & $\mathrm{C}_{2} \mathrm{~S}_{1}$ \\
\hline Textural class & sandy clay loam & $\mathrm{OM}\left(\mathrm{g} \mathrm{kg}^{-1}\right)$ & 21.83 & & \\
\hline
\end{tabular}

$\mathrm{Cs}=$ Coarse sand; Fs = Fine sand; Dcw = dispersed clay on water; Df = degree of flocculation (clay - Acw/clay)*100; $\mathrm{Ds}=$ bulk density; $\mathrm{Pd}=$ particle density; Tp = total porosity; $(1-(\mathrm{Ds} / \mathrm{Pd}) * 100) ; \mathrm{Ucc}=$ volumetric soil humidity at field capacity $-0.033 \mathrm{MPa} ; \mathrm{Upmp}=$ volumetric soil moisture at the permanent wilting point $-1.5 \mathrm{MPa} ; \mathrm{Wa}=$ water available, OM = organic matter; $\mathrm{PST}=$ exchangeable sodium percentage; $\mathrm{Sb}=$ Sum of bases $\left(\mathrm{Ca}^{+2}+\mathrm{Mg}^{+2}+\mathrm{K}^{+}+\mathrm{Na}^{+}\right) ; \mathrm{CEC}=$ cation exchange capacity $=\left[\mathrm{SB}+\left(\mathrm{H}^{+}+\mathrm{Al}^{+3}\right)\right] ; \mathrm{V}=$ base saturation $=(\mathrm{SB} / \mathrm{CEC}) \times 100 ; \mathrm{m}=$ aluminum saturation $\left(100 \times\left.\mathrm{Al}\right|^{3}\right) / \mathrm{T}=(100 \times$ $\left.\left.\mathrm{Al}^{3}\right) / \mathrm{Ca}^{+2}+\mathrm{Mg}^{+2}+\mathrm{K}^{+}+\mathrm{Na}^{+}+\left.\mathrm{Al}\right|^{+3}\right) ; \mathrm{SAR}=$ sodium adsorption ratio $\left[\mathrm{Na}^{+} /\left(\mathrm{Ca}^{2+}+\mathrm{Mg}^{2+} / 2\right)^{1 / 2}\right]$. Water classification according to Richards (1954).

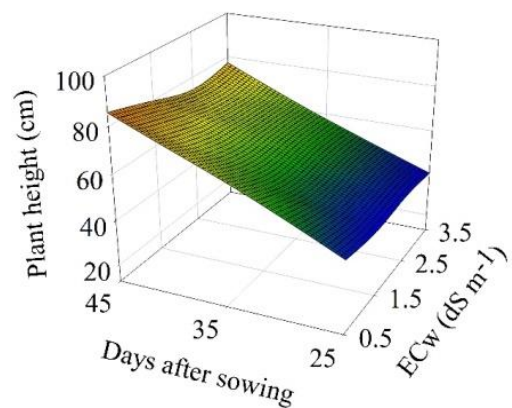

Fig 1. Plant height of ornamental sunflower plant "Sol noturno" irrigated with saline water at 25, 35 and 45 DAS.

Table 2. Averages relating to growth rates absolute (AGRph) and relative (RGRph) of height and stem diameter (AGRsd and RGRsd), maximal fluorescence $(\mathrm{Fm})$, variable fluorescence $(\mathrm{Fv})$, maximum efficiency of the photochemical process in PSII (Fv/Fo), quantum efficiency of photosystem ( $\mathrm{Fv} / \mathrm{Fm}$ ) and instantaneous efficiency using ornamental sunflower plants water irrigated with waters of different electrical conductivities and silicon rates.

\begin{tabular}{|c|c|c|c|c|c|c|c|c|}
\hline \multirow[b]{2}{*}{$\begin{array}{l}\text { ECw } \\
\left(\mathrm{dS} \mathrm{m} \mathrm{m}^{-1}\right)\end{array}$} & \multicolumn{8}{|c|}{ Variables } \\
\hline & AGRph & RGRph & AGRsd & RGRsd & $\mathrm{Fm}$ & Fv & Fv/Fo & $\mathrm{Fv} / \mathrm{Fm}$ \\
\hline 0.5 & $2.15 a$ & $0.0218 a$ & $0.1506 a$ & $0.0110 a$ & $164.80 a$ & $164.50 a$ & $595.84 a$ & $835.80 a$ \\
\hline 1.5 & $2.05 a$ & $0.0213 a$ & $0.1424 a$ & $0.0106 a$ & $156.47 a$ & $156.20 \mathrm{a}$ & 588.83a & 721.13a \\
\hline 2.5 & $1.89 a$ & $0.0207 a$ & $0.1446 a$ & 0.0109a & 157.93a & 157.67a & $606.72 a$ & $637.13 a$ \\
\hline 3.5 & $1.99 a$ & $0.0216 a$ & $0.1436 a$ & $0.0109 a$ & $160.53 a$ & $160.28 a$ & $642.07 a$ & $545.20 a$ \\
\hline $\begin{array}{l}\text { Si } \\
\left(\mathrm{mg} \mathrm{L}^{-1}\right)\end{array}$ & AGRph & RGRph & AGRsd & RGRsd & $\mathrm{Fm}$ & Fv & Fv/Fo & $\mathrm{Fv} / \mathrm{Fm}$ \\
\hline 0 & $1.90 a$ & $0.020 \mathrm{~b}$ & $0.150 a$ & $0.011 a$ & $163.75 a$ & $163.46 a b$ & $636.13 a$ & $702.25 a$ \\
\hline 50 & $1.96 a$ & $0.021 a b$ & $0.127 a$ & 0.010a & $150.75 a$ & $150.48 b$ & 551.86a & 666.83a \\
\hline 100 & $2.17 a$ & $0.023 a$ & $0.152 a$ & $0.012 a$ & 171.33a & 171.07a & $638.73 a$ & 691.75a \\
\hline 150 & $2.25 a$ & $0.022 a$ & $0.147 a$ & $0.011 a$ & $162.17 a$ & 161.90ab & 617.77a & $690.67 a$ \\
\hline 200 & $1.82 a$ & $0.020 \mathrm{~b}$ & $0.151 a$ & $0.011 a$ & $151.67 a$ & $151.41 b$ & $597.32 a$ & $672.58 \mathrm{a}$ \\
\hline
\end{tabular}

* Means followed by the same letter do not differ statistically by the Tukey test at $5 \%$ probability.
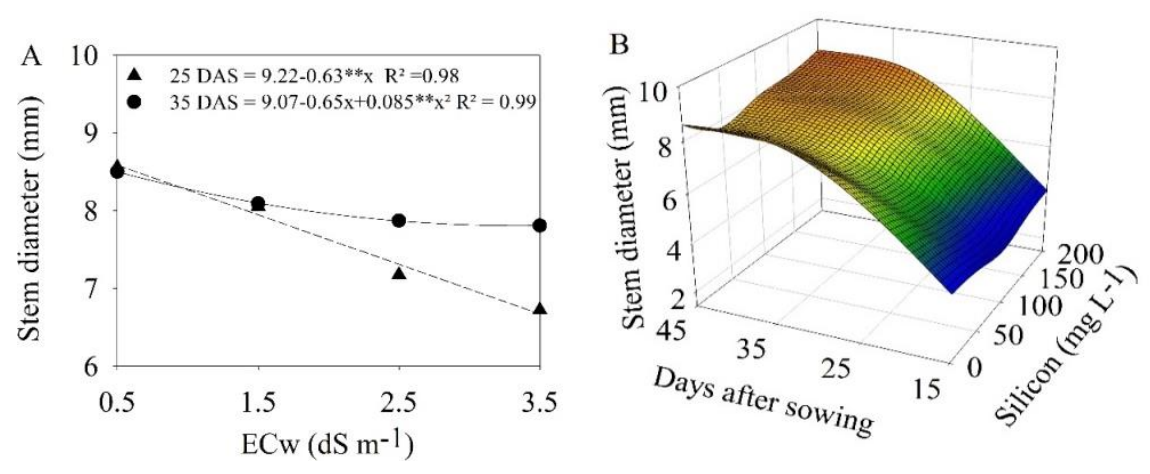

Fig 2. Stem diameter of ornamental sunflower plants "Sol noturno" irrigated with saline water at 25 and 35 DAS (A) and at 15,35 and 45 DAS (B) in function of silicon rates. 


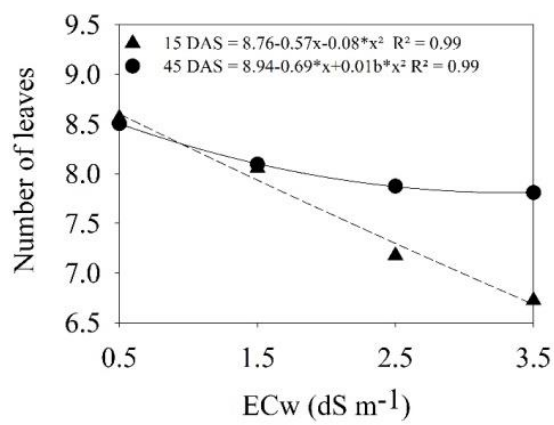

Fig 3. Number of leaves of ornamental sunflower plants "Sol noturno" under irrigation with saline water at 15 and 45 DAS.
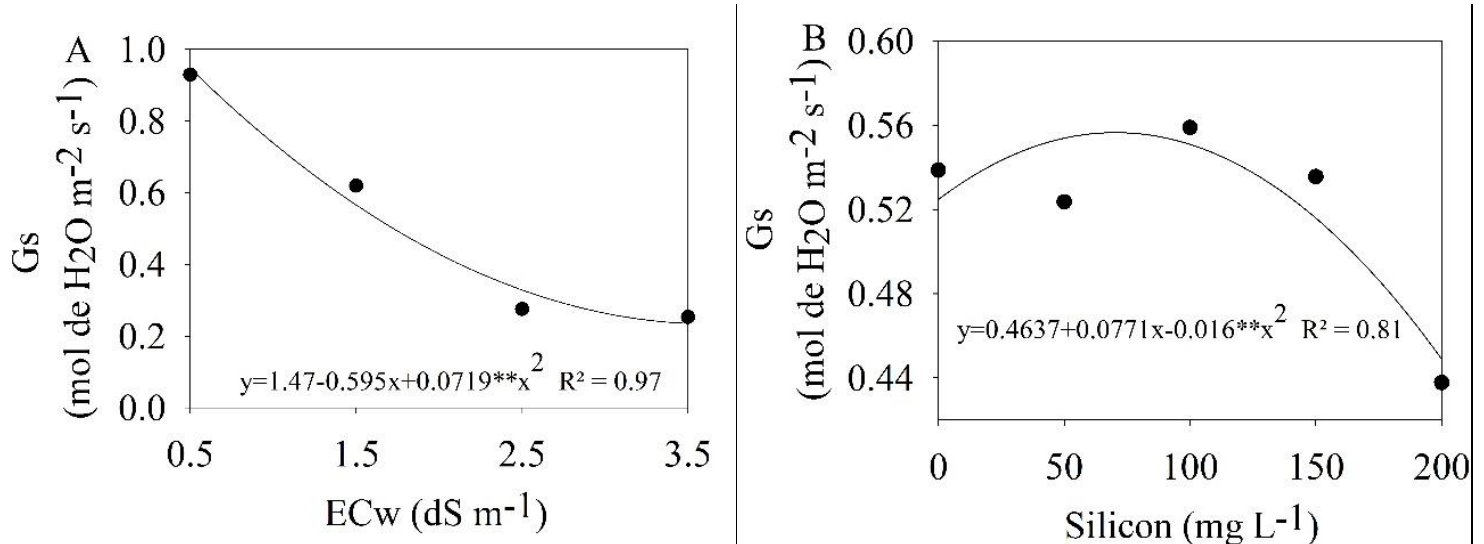

Fig 4. Stomatal conductance (Gs) of ornamental sunflower plants "Sol noturno" irrigated with saline water (A) and silicon rates (B).

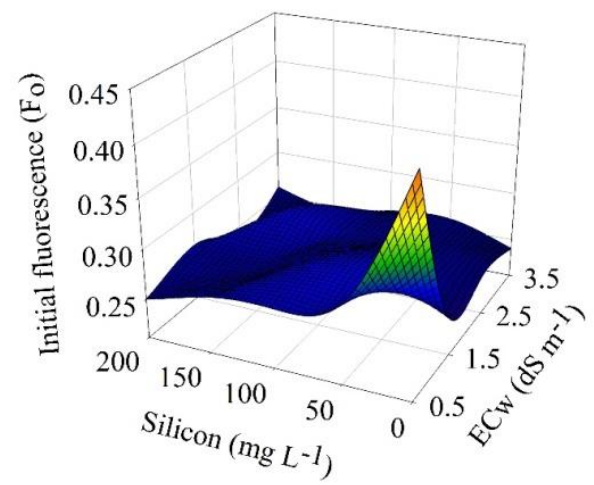

Fig 5. Initial Fluorescence of ornamental sunflower plants "Sol noturno" irrigated with water and silicon rates.

reflecting negatively on photosynthetic activity (Calvet et al., 2013). Santos et al. (2017) observed that the increase in ECw levels reduced the number of leaves in sunflower plants $\mathrm{cv}$. "EMBRAPA 122-V2000", with decreases of 6.20, 6.37, 7.09 and $4.09 \%$ at $15,30,45$, and 60 DAS for each unit of ECW.

\section{Stomatal conductance}

The increase of salt concentration in the irrigation water still compromised $73.11 \%$ stomatal conductance of ornamental sunflower plants, then the greater stomatal conductance was observed in plants managed with water of $0.5 \mathrm{dS} \mathrm{m}^{-1}$

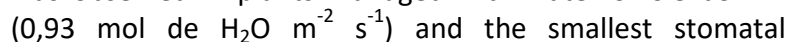
conductance $\left(0.25 \mathrm{~mol}\right.$ de $\left.\mathrm{H}_{2} \mathrm{O} \mathrm{m}^{-2} \mathrm{~s}^{-1}\right)$ with irrigation water of $3.5 \mathrm{dS} \mathrm{m}^{-1}$ (Figure $4 \mathrm{~A}$ ).

This reduction may have been caused mainly due to water stress (drought), to which the ornamental sunflower plants were subjected, in this way an alternative to reduce the transpiration rate is the stomatal closure. However, with the stomatal closure there is a reduction in photosynthetic rate due to the lower availability of $\mathrm{CO}_{2}$ (Pereira et al., 2012), causing a reduction in the plants growth and development, corroborating the data obtained in this study.

The Si rates provided an increased stomatal conductance of ornamental sunflower plants, reaching the maximum point of $0.56 \mathrm{~mol}_{\text {de }} \mathrm{H}_{2} \mathrm{O} \mathrm{m}^{-2} \mathrm{~s}^{-1}$ in rate of $100 \mathrm{mg} \mathrm{L}^{-1}$, that is, an increase of $3.70 \%$. However, by increasing the $\mathrm{Si}$ rates there was reduction from $27.27 \%$ to $200 \mathrm{mg} \mathrm{L}^{-1}$, being observed the lowest stomatal conductance $\left(0.44 \mathrm{~mol}^{2} \mathrm{He}_{2} \mathrm{O} \mathrm{m}^{-2} \mathrm{~s}^{-1}\right)$ in this Si rate (Figure 4B).

The occurrence of this behavior may be attributed to the beneficial effects of $\mathrm{Si}$, among them, the formation of a physical layer in leaves, promoting the reduction in transpiration, it may have facilitated the stomatal opening of sunflower plants (Heckman, 2013). However, higher Si rates, such as above $100 \mathrm{mg} \mathrm{L}^{-1}$ may be responsible for toxicity in ornamental sunflower plants, affecting their stomatal opening.

The results on Figure 4 confirm those obtained by Ferraz et al. (2014) in cotton cultivation, it was observed that the increase of $\mathrm{Si}$ rates decreased stomatal conductance, reaching the highest conductance in plants that did not 
receive $\mathrm{Si}$ application. The increase of $\mathrm{Si}$ rates from the optimal rate $\left(100 \mathrm{mg} \mathrm{L}^{-1}\right)$ also reduced stomatal conductance of ornamental sunflower plants (Figure 4).

\section{Initial Fluorescence}

The increase of $\mathrm{ECW}$ and the $\mathrm{Si}$ rates reduced the initial fluorescence of ornamental sunflower plants reaching higher initial fluorescence $(0.42)$ in plants irrigated with water of $0.5 \mathrm{dS} \mathrm{\textrm {m } ^ { - 1 }}$ without application $\mathrm{Si}$, against 0.24 of initial fluorescence in plants irrigated with the same water and $\mathrm{Si}$ rate of $150 \mathrm{mg} \mathrm{L}^{-1}$, with $75 \%$ reduction in the initial fluorescence (Figure 5).

The reduction of initial fluorescence of chlorophyll a is due to one of the most harmful effects of salt stress, which is the damage to the photosynthetic apparatus, as well, biosynthesis of photosynthetic pigments changes, limiting the electron transport in chloroplasts, with consequent reduction in the photochemical efficiency of photosystem II (Yin et al., 2013).

Recent studies have also evidenced beneficial effects of $\mathrm{Si}$ on the growth of several plant species (canola, soy, wheat, sorghum, tomatoes and corn) under salt stress conditions, increasing the leaf area, chlorophyll content and improved the structure of chloroplasts, which resulted in increased photosynthetic activity (Tahir et al., 2012; Yin et al., 2013).

The relative and absolute growth rates of height and stem diameter, maximal fluorescence $(\mathrm{Fm})$, variable fluorescence (Fv), maximum photosystem II photochemical efficiency (Fv/Fo), photosystem II quantum efficiency (Fv/Fm) and instantaneous water use efficiency, although they have presented significant effect for ECW levels and silicon rates, they did not fit the applied regression models.

It was observed that irrigation with lower water salinity (0.5

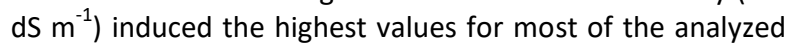
variables, except maximum efficiency of the photochemical process in PSII (Fv/Fo) that presented the highest value when the ornamental sunflower plants were irrigated with $3.5 \mathrm{dS} \mathrm{m}^{-1}$. It was also found that the Si rate of $100 \mathrm{mg} \mathrm{L}^{-1}$ provided higher values for relative and absolute growth rates of plant height and stem diameter, maximal fluorescence $(\mathrm{Fm})$, variable fluorescence $(\mathrm{Fv})$, maximum efficiency of the photochemical process in PSII (Fv/Fo), except photosystem II quantum efficiency (Fv/Fm) (Fv/Fm) which was greater without the application of silicon (Table 2).

\section{Materials and Methods}

\section{Plant material}

Ornamental sunflower seeds cv. "Sol noturno" were sown directly into polyethylene bags. At ten days after germination, a selection of the most vigorous seedling was done, and the other plants were thinned.

\section{Experimental area location and design}

The experiment was conducted in a greenhouse located at the olericulture sector, belonging to the Federal University of Paraíba in Areia-PB, Brazil, located in the geographical coordinates 6051'47 "and 7002'04" S and 3534'13 "and 35048' $28^{\prime \prime}$ W of the Greenwich meridian.

The experimental design was entirely randomized conducted in a factorial $4 \times 5$ with 6 replicates, related to four electrical conductivity of the irrigation water (ECw): $0.5 ; 1.5 ; 2.5$ and $3.5 \mathrm{dS} \mathrm{m}^{-1}$ five silicon rates: $0,50,100,150$ and $200 \mathrm{mg} \mathrm{L}^{-1}$. The experimental units were composed of three plants cultivated in polyethylene bags with a capacity of $5 \mathrm{dm}^{3}$.

\section{Soil preparation}

The polyethylene bags were filled with soil classified as eutrophic Regolithic Neosol (Embrapa, 2014), sandy clay loam texture non saline and non sodic, from the Chã-deJardim community, municipality of Areia, PB, the chemical analysis and the results are presented in Table 1.

\section{Irrigation}

The ornamental sunflower plants were irrigated daily, rising at the beginning the soil moisture about $80 \%$ of field capacity $(\mathrm{Fc})$. The replacement of the water by plants evotranspiration $(E T C)$ occurred due to the evaporation of class ' $A$ ' pan (ECA) and the crop coefficient $(K C)$ in different plants phenological stages. The different $\mathrm{ECW}$ were obtained by use of the salts $\mathrm{NaCl}, \mathrm{CaCl}_{2} \cdot 2 \mathrm{H}_{2} \mathrm{O}$ and $\mathrm{MgCl}_{2} \cdot 6 \mathrm{H}_{2} \mathrm{O}$ at a ratio of 7:2:1. Irrigation with water of different salinities was initiated after thinning of seedlings. The water used for irrigation was analyzed and the results are presented in Table 1.

\section{Silicon application}

The application of silicon was done manually with a manual atomizer having as a source liquid potassium silicate $\left(\mathrm{K}_{2} \mathrm{SiO}_{3}\right)$ with $12 \% \mathrm{Si}$ and $15 \% \mathrm{~K}_{2} \mathrm{O}$. The application was done weekly, a total of four applications. Each treatment was diluted in $100 \mathrm{ml}$ of water and applied at the respective Si rates, which were divided into four applications at 15, 30, 45 and 60 days after emergence. Due to the source of silicon (potassium silicate) containing $15 \% \mathrm{~K}_{2} \mathrm{O}$, was proceeded compensation via fertigation for each treatment by subtracting the amount of $\mathrm{K}$ applied by foliar fertilizing topdressing with $\mathrm{KCl}$, thereby maintaining the homogeneity of the element regardless of treatment.

\section{Analyzed variables}

The effect of the treatments on the ornamental sunflower was evaluated at 15, 25, 35 and 45 days after sowing by determining plant height (measurement with a ruler graduated in $\mathrm{cm}$ ), stem diameter (com digital caliper), leaf number, and absolute and relative growth rate.

Physiological indices such as absolute growth rate (AGR) and relative growth rate (RGR) where determined by plant height and stem diameter every 15 days until the end of the experiment through its respective mathematical formulas of according to the methodology of Benincasa (2003).

At the end of the experiment, that is after 60 days, measurements were performed: initial fluorescence (Fo), Maximal fluorescence $(\mathrm{Fm})$, variable fluorescence (Fv), maximum photosystem II photochemical efficiency (Fv/Fo) and the photosystem II quantum efficiency $(\mathrm{FSII}=\mathrm{Fv} / \mathrm{Fm})$ using a modulated fluorometer named Plant Efficiency Analyzer - PEA II (Hansatech Instruments Co, UK). Measures were taken from the third leaf counted from the apex of the plant, pre-adapted to dark with leaf clamps between 6 and 7 h during $30 \mathrm{~min}$. 
Ornamental sunflower gas exchanges were evaluated at 45 DAS by determining stomatal conductance (gs) ( ( mol de $\mathrm{H}_{2} \mathrm{O}$ $\mathrm{m}^{-2} \mathrm{~s}^{-1}$ ) and instantaneous water use efficiency (EiUA - A/E) calculated by relating the net photosynthetic rate divided by

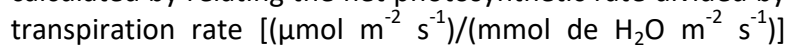
using the infrared gas analyzer (IRGA) model LCpro+Sistem.

\section{Statistical analysis}

Results were submitted to the variance analysis by $\mathrm{F}$ test ( $\mathrm{p}$ $<0.05$ ). For variables with significant interaction effect were fitted to the response surface, and otherwise was conducted polynomial regression analysis. Statistical analyses were performed using the statistical software SAS ${ }^{\circ}$ (Cody, 2015).

\section{Conclusions}

The salinity in the irrigation water reduces growth, the fluorescence of chlorophyll a and stomatal opening of ornamental sunflower plants.

The application of silicon above $100 \mathrm{mg} \mathrm{L}^{-1}$ promotes a decrease in stomatal conductance of ornamental sunflower. It is recommended to irrigate ornamental sunflower plants "Sol noturno" with water of $0.5 \mathrm{dS} \mathrm{m}^{-1}$ and to apply $100 \mathrm{mg}$ $\mathrm{L}^{-1}$ of silicon.

\section{Acknowledgments}

To Brazilian National Council for Scientific and Technological Development (CNPq) and for Coordination for the Improvement of Higher Education Personnel (CAPES) for scholarships concessions.

\section{References}

Alzahrani Y, Kuşvuran A, Alharby HF, Kuşvuran S, Rady MM (2018) The defensive role of silicon in wheat against stress conditions induced by drought, salinity or cadmium. Ecotoxicology and environmental safety. 154:187-196.

Benincasa MMP (2003) Análise de crescimento de plantas, noções básicas. 2 ed. Jaboticabal: FUNEP. 41p.

Calvet ASF, Pinto CDM, Lima REM, Maia-Joca RPM, Bezerra MA (2013) Crescimento e acumulação de solutos em feijão-caupi irrigado com águas de salinidade crescente em diferentes fases de desenvolvimento. Irriga. 18(1): 148-159.

Cody, R. 2015. An Introduction to SAS University Edition. Cary, NC. SAS Institute, 366p.

Ferraz RLDS, Beltrão NEDM, Melo ASD, Magalhaes ID, Fernandes PD, Rocha MDS (2014). Trocas gasosas e eficiência fotoquímica de cultivares de algodoeiro herbáceo sob aplicação de silício foliar. Semina: Ciências Agrárias. 35(2): 735-748.

Gomes FAL, Araújo RHCR, Nóbrega JS, Fátima RT, Silva MS, Santos AS, Teodósio AEMM, Oliveira CJA (2018) Application of silicon to alleviate irrigation water salinity in melon growth. Journal of Experimental Agriculture International. 25(6): 1-9.

Guntzer F, Keller C, Meunier JD (2012) Benefits of plant silicon for crops: a review. Agronomy for Sustainable Development. 32(1): 201-213.

Heckman BJ (2013) Silicon: A Beneficial Substance. Better Crops. 97(4): 14-16.

Islam MN, Islam A, Biswas JC (2017) Effect of gypsum on electrical conductivity and sodium concentration in salt affected paddy soil. International Journal of Agricultural Papers. 2(1): 19-23.

Maia JM, Macêdo CEC, Silveira JAG, Silva AF, Lira EHA, Melo AS, Meneses CHSG (2015) Seca e salinidade na resposta antioxidativa de raízes de feijão caupi. Journal of Biology \& Pharmacy and Agricultural Management. 11(1): 59-93.
Mushke R, Yarra R, Kirti PB (2019) Improved salinity tolerance and growth performance in transgenic sunflower plants via ectopic expression of a wheat antiporter gene (TaNHX2). Molecular Biology Reports. 1-13.

Oliveira MLA, Silva Paz VP, Gonçalves KS, Oliveira GXS (2017) Crescimento e produção de girassol ornamental irrigado com diferentes lâminas e diluições de água residuária. Irriga. 22(2): 204-219.

Pereira TS, Lobato AKS, Tan DKY, Costa DV, Uchoa EB, Ferreira RN, Guedes EMS (2013) Positive interference of silicon on water relations, nitrogen metabolism, and osmotic adjustment in two pepper (Capsicum annuum) cultivars under water deficit. Australian Jornal of Crop Science. 7(8): 1064-1071.

Ribeiro PHP, Silva S, Neto JD, Oliveira CS, Chaves LHG (2015) Crescimento e componentes de produção do girassol em função da irrigação com água salina e adubação nitrogenada. Revista Engenharia na Agricultura. 23(1): 48-56.

Sahebi M, Hanafi MM, Azizi P (2016) Application of silicon in plant tissue culture. In Vitro Cellular and Developmental Biology-Plant. 52(3): 226-232.

Santos Júnior JA, Gheyi HR, Soares FA, Dias NDS (2013) Efficiency of water use for sunflower grown in hydroponic system under salt stress. Engenharia Agrícola. 33(4): 718-719.

Santos JBD, Centeno CRM, Azevedo CAVD, Gheyi HR, Lima GS, Lira VM (2017) Crecimiento del girasol (Helianthus annuus L.) en función de la salinidad del agua de riego con fertilización nitrogenada. Agrociencia. 51(6): 649-660.

Sarwar Y, Shahbaz M (2019) GR24 Triggered Variations in MorphoPhysiological Attributes of Sunflower (Helianthus annuus) under Salinity. International Journal of Agriculture and Biology. 21(1): 34-40.

Shahzad M, Witzel K, Zörb C, Mühling KH (2012) Growth-Related Changes in Subcellular Ion Patterns in Maize Leaves (Zea mays L.) under Salt Stress. Journal of Agronomy \& Crop Science. 198(1): 46-56.

Silva FD, Lacerda CD, Neves ALR, Sousa GD, Sousa CD, Ferreira FJ (2013) Irrigação com águas salinas e uso de biofertilizante bovino nas trocas gasosas e produtividade de feijão-de-corda. Irriga. 18(2): 304-317.

Silva LC, Paiva PDO, Santos AC (2015) Flower and ornamental plants wholesale markets in Brazil. Ornamental Horticulture. 21(1): 5362.

Silva TGF, Zolnier S, Grossi JAS, Barbosa JG, Moura CRW, Muniz MA (2009) Crescimento do girassol ornamental cultivado em ambiente protegido sob diferentes níveis de condutividade elétrica de fertirrigação. Revista Ceres. 56(5): 602-610.

Sousa Júnior R, Lima GS, Gheyi HR, Lima VLA, Santos JB, Sousa JRM, Freitas Furtado G (2017) Gas exchange and production of sunflower ('Helianthus annuus' L.) irrigated with water of different salinity, cationic nature and nitrogen doses. Australian Journal of Crop Science. 11(3): 300-307.

Tahir MA, Aziz T, Farooq M, Sarwar G (2012) Silicon-induced changes in growth, ionic composition, water relations, chlorophyll contents and membrane permeability in two salt-stressed wheat genotypes. Archives of Agronomy and Soil Science. 58(3): 247-56.

Wanderley CS, Faria RT, Rezende R (2014) Crescimento de girassol como flor em vaso em função de doses de paclobutrazol. Revista Ceres. 61(1): 35-41.

Yadav S, Irfan M, Ahmad A, Hayat S (2011) Causes of salinity and plant manifestations to salt stress: A review. Journal of Environmental Biology. 32(5): 667-685.

Yin L, Wang S, Li J, Tanaka K, Oka M (2013) Application of silicon improves salt tolerance through ameliorating osmotic and ionic stresses in the seedling of Sorghum bicolour. Acta Physiologiae Plantarum. 35(11): 1-9.

Zhu Y, Gong H (2014) Beneficial effects of silicon on salt and drought tolerance in plants. Agronomy for Sustainable Development. 34(2): 455-472. 